\title{
First Record of the Fish Louse Argulus quadristriatus (Branchiura: Arguloida: Argulidae) from Japanese Waters, with Three New Host Records
}

\author{
Daisuke Uyeno ${ }^{1,4}$, Wataru Miyazaki², and Kazuya Nagasawa ${ }^{3}$ \\ ${ }^{1}$ Graduate School of Science and Engineering, Kagoshima University, 1-21-35 Korimoto, Kagoshima 890-0065, Japan \\ E-mail:duyeno@sci.kagoshima-u.ac.jp \\ 2 The Kagoshima City Aquarium, 3-1 Honko-Shinmachi, Kagoshima 892-0814, Japan \\ E-mail:w-miyazaki@ioworld.jp \\ ${ }^{3}$ Graduate School of Biosphere Science, Hiroshima University, 1-4-4 Kagamiyama, Higashi-Hiroshima, Hiroshima 739-8528, Japan \\ E-mail:ornatus@hiroshima-u.ac.jp \\ ${ }^{4}$ Corresponding author
}

(Received 16 July 2016; Accepted 28 October 2016)

\begin{abstract}
An argulid branchiuran, Argulus quadristriatus Devaraj and Ameer Hamsa, 1977, is reported on the basis of specimens of both sexes isolated from two species of goatfish [Upeneus tragula Richardson, 1846 and Parupeneus ciliatus (Lacepède, 1802) (Perciformes: Mullidae)] and the goby Favonigobius reichei (Bleeker, 1854) (Perciformes: Gobiidae) collected in Kagoshima Bay and off both the east and west coasts of Okinawa-jima island, southern Japan. The branchiuran is easily distinguished from its nine previously recorded congeners in Japanese waters by the presence of one posterior spine on the antennule and scales ornamenting the basal half of the mouthtube. These are the first records of this branchiuran from the North Pacific Ocean including Japanese waters, and the three fish species mentioned above are new hosts for it.
\end{abstract}

Key Words: Branchiura, Argulidae, fish lice, Kagoshima Bay, Okinawa-jima island, new record.

\section{Introduction}

The crustacean subclass Branchiura Thorell, 1864 contains about 175 species classified in four genera (Argulus Müller, 1785, Chonopeltis Thiele, 1900, Dipteropeltis Calman, 1912, and Dolops Audouin, 1837) within a single family, Argulidae Leach, 1819, and is known as one of the groups of ectoparasites of fishes (Boxshall 2005; Poly 2009). Three of these genera occur only in fresh waters of non-Asian countries (viz., Dipteropeltis in South America, Chonopeltis in Africa, and Dolops in South America, Africa, and Tasmania) (Poly 2009; Neethling et al. 2014). Argulus, which is the most species-rich genus of the family, comprises 129 valid species from all continents and surrounding waters, except Antarctica. Of these species, 85 and 44 species were found in fresh and marine waters, respectively (Poly 2008). According to Poly (2008), at least 12 additional undescribed species of Argulus exist in fresh waters of North America and Australia. In Japanese waters, nine species of the genus have been recorded (Nagasawa 2009, 2011).

In this study, Argulus quadristriatus Devaraj and Ameer Hamsa, 1977 is recorded on the basis of both sexes collected from two species of goatfish, Upeneus tragula Richardson, 1846 and Parupeneus ciliatus (Lacepède, 1802) (Perciformes: Mullidae), and a species of goby, Favonigobius reichei (Bleeker, 1854) (Perciformes: Gobiidae), from Kagoshima Bay and coastal waters of Okinawa-jima island, southern Japan.

\section{Materials and Methods}

Branchiurans were carefully taken from fish captured by SCUBA divers with small round net and then fixed in $80 \%$ ethanol. Subsequently, they were soaked in lactophenol for about 24 hrs, dissected, and examined using a modified version of the wooden slide method described by Humes and Gooding (1964) and Benz and Otting (1996). Drawings were made with the aid of a stereomicroscope, a compound microscope, and a drawing tube. Body parts of argulids were measured using a slide caliper and an ocular micrometer, and measurements are given in millimeters $(\mathrm{mm})$. The body length was measured from the rostral area to the posterior tip of the abdomen. The terminology follows Cressey (1972) and Benz and Otting (1996). Specimens examined are deposited in the crustacean collection $(\mathrm{Cr})$ of the National Museum of Nature and Science, Tsukuba (NSMT), Japan, the arthropod collection (AT) of the Kagoshima University Museum (KAUM), Kagoshima, Japan, and the crustacean collection (ZC) of the Ryukyu University Museum, Fujukan (RUMF), University of the Ryukyus, Okinawa, Japan.

Genus Argulus Müller, 1785

Argulus quadristriatus Devaraj and Ameer Hamsa, 1977

(Figs 1-5)

Argulus quadristriatus Devaraj and Ameer Hamsa, 1977: 129-133, figs 1-11. 

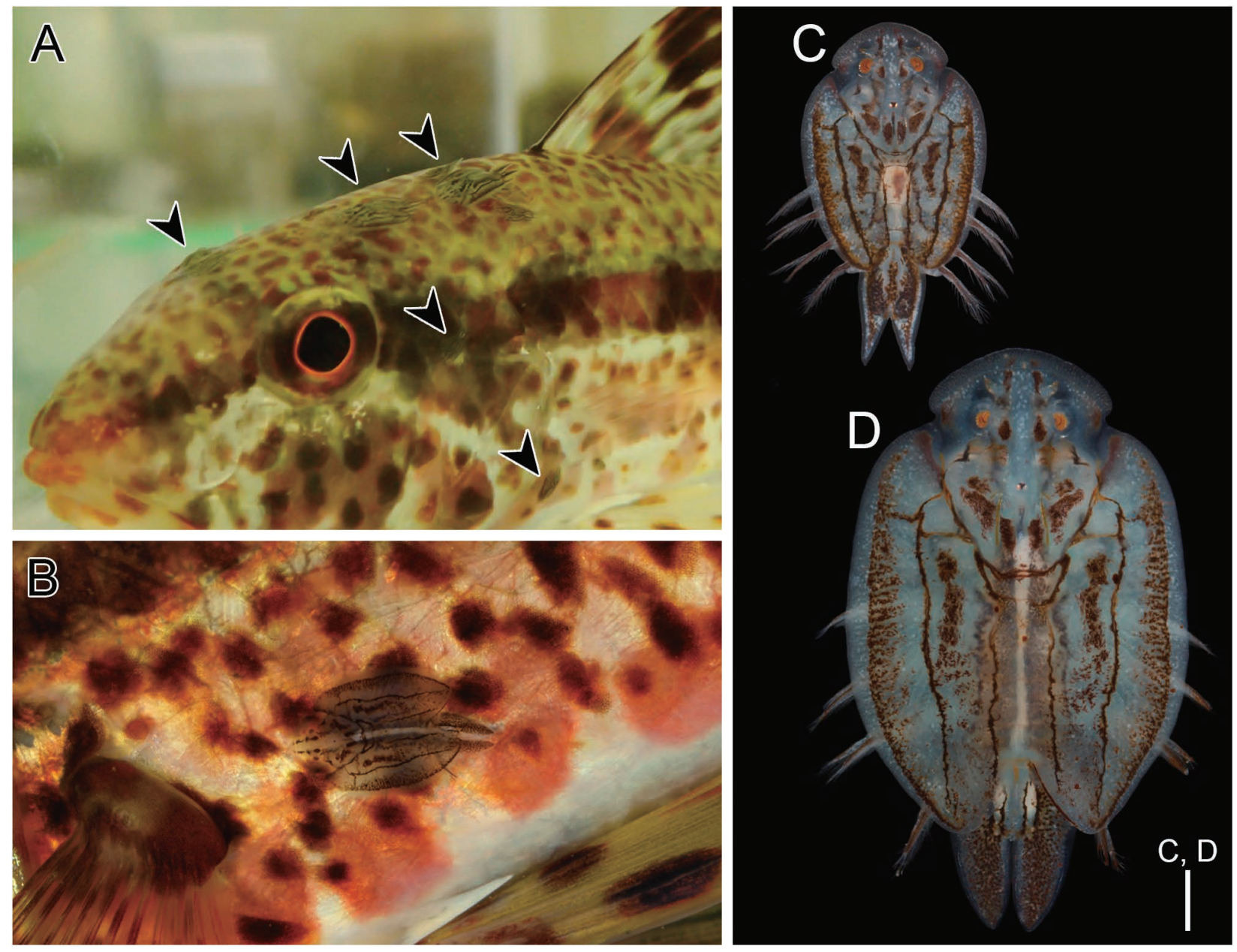

Fig. 1. Live specimens of the goatfish Upeneus tragula Richardson and Argulus quadristriatus Devaraj and Ameer Hamsa, 1977. A, a live host (ca. $14 \mathrm{~cm} \mathrm{SL}$ ) infected by branchiurans (arrowheads) in a tank of Kagoshima City Aquarium; B, an adult female attached on the body surface near the base of the pectoral fin of the host; C, live coloration of an adult male, NSMT-Cr 24635, dorsal; D, live coloration of an adult female, NSMT-Cr 24635, dorsal. Scale bar: $1 \mathrm{~mm}$.

Material examined. 1 adult male and 2 adult females (NSMT-Cr 24635), ex Upeneus tragula Richardson (Perciformes: Mullidae), in Iruka Channel $\left(31^{\circ} 35^{\prime} 44.52^{\prime \prime} \mathrm{N}\right.$, $\left.130^{\circ} 33^{\prime} 48.96^{\prime \prime} \mathrm{E}\right)$, Kagoshima Bay, Kyushu, Japan, 28 February 2016, leg. W. Miyazaki and Y. Kashiwagi; 1 adult female (KAUM-AT-289), collection data same as NSMT-Cr 24635; 1 developmental stage, male (NSMT-Cr 24636), ex Favonigobius reichei (Bleeker) (Perciformes: Gobiidae) (BLIP20050305 stored in Biological Laboratory), off mouth of Nagahama River $\left(26^{\circ} 25^{\prime} \mathrm{N}, 127^{\circ} 44^{\prime} \mathrm{E}\right)$, Onna, Okinawajima island, East China Sea, Japan, 26 July 2005, leg. K. Abe; 1 developmental stage, female (RUMF-ZC-04356), ex Parupeneus ciliatus (Lacepède) (Perciformes: Mullidae), Kin Bay off "Kaichu-doro" roadway $\left(26^{\circ} 20^{\prime} \mathrm{N}, 127^{\circ} 55^{\prime} \mathrm{E}\right)$ connecting Okinawa-jima island to Henza-jima island, Japan, 2 May 2011, leg. S. Samejima.

Description of adult male. Body (Figs 1C, 2A) 6.00 long $(n=1)$, comprising cephalon, four thoracic somites, and abdomen. Cephalon longer than wide, $4.30 \times 3.44$, bearing pair of compound eyes and nauplius eye, compound eye bean-shaped, 0.24 long, with medial cleft on posterior margin extending on posterior margin of second thoracic so- mite and pair of carapace lobes; ventral surface covered with pointed spinules on frontal region and lateral margins (Fig. $2 \mathrm{~B})$; respiratory areas composed of small, round anterior region and wedge-shaped posterior region (Fig. 2B). First to fourth thoracic somites covered with spinules on ventral surface (Fig. 2B); fourth thoracic somite bearing oval fleshy lobe posteroventrally (Figs $2 \mathrm{~B}, 3 \mathrm{H}$ ). Abdomen (Fig. 2A, B) bilobate, longer than wide, $4.17 \times 2.33$; each lobe with triangular posterior tip; caudal rami (Fig. 2C) located in cleft between lobes, rod-like, longer than wide, $0.04 \times 0.03$, with median constriction, each bearing five simple setae.

Antennule (Fig. 2D) 4-segmented; proximal segment robust, bearing pointed posterior spine; second segment robust, bearing curved hook-like anterior and terminal spines and pointed medial spine; third segment rod-like, bearing two distal setae; terminal segment rod-like, bearing seven distal setae. Antenna (Fig. 2D) 4-segmented; proximal segment robust, subdivided by constriction at mid-length, six setae and pointed process on proximal half and eight setae on terminal half; second segment bearing 13 setae; third segment bearing six setae; terminal segment bearing six distal setae. Postantennal spine (Fig. 2D) robust, with coni- 


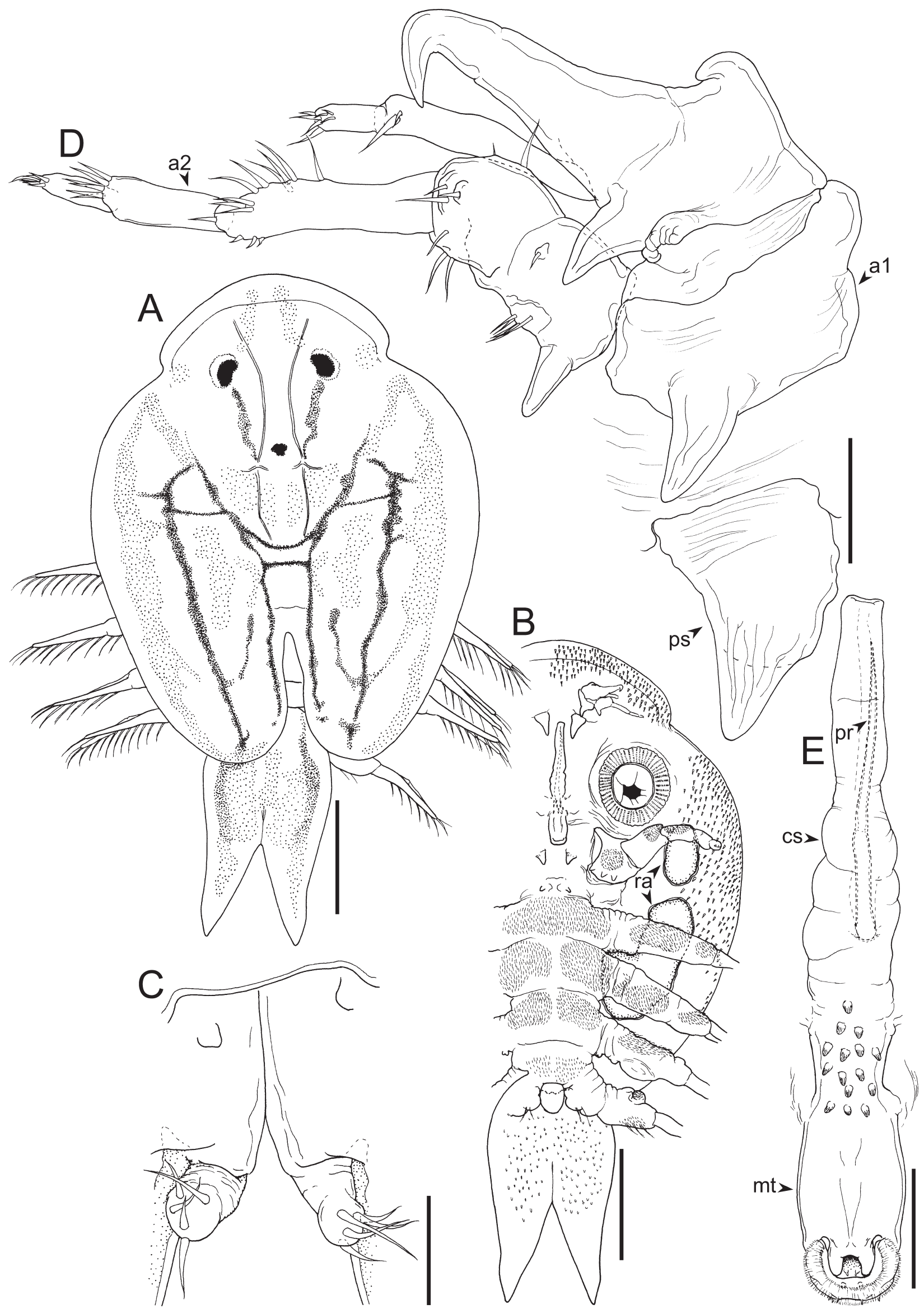

Fig. 2. Argulus quadristriatus Devaraj and Ameer Hamsa, 1977, adult male, NSMT-Cr 24635. A, habitus, dorsal; B, partial habitus, ventral $(\mathrm{ra}=$ respiratory areas); $\mathrm{C}$, caudal rami, dorsal; D, antennule (a1), antenna (a2), and postantennal spine (ps), ventral; E, mouthtube (mt), preoral stylet (pr), and cuticular sheath (cs), ventral. Scale bars: A, B, $1 \mathrm{~mm} ; \mathrm{C}, 0.05 \mathrm{~mm} ; \mathrm{D}, 0.1 \mathrm{~mm}$; E, $0.1 \mathrm{~mm}$. 

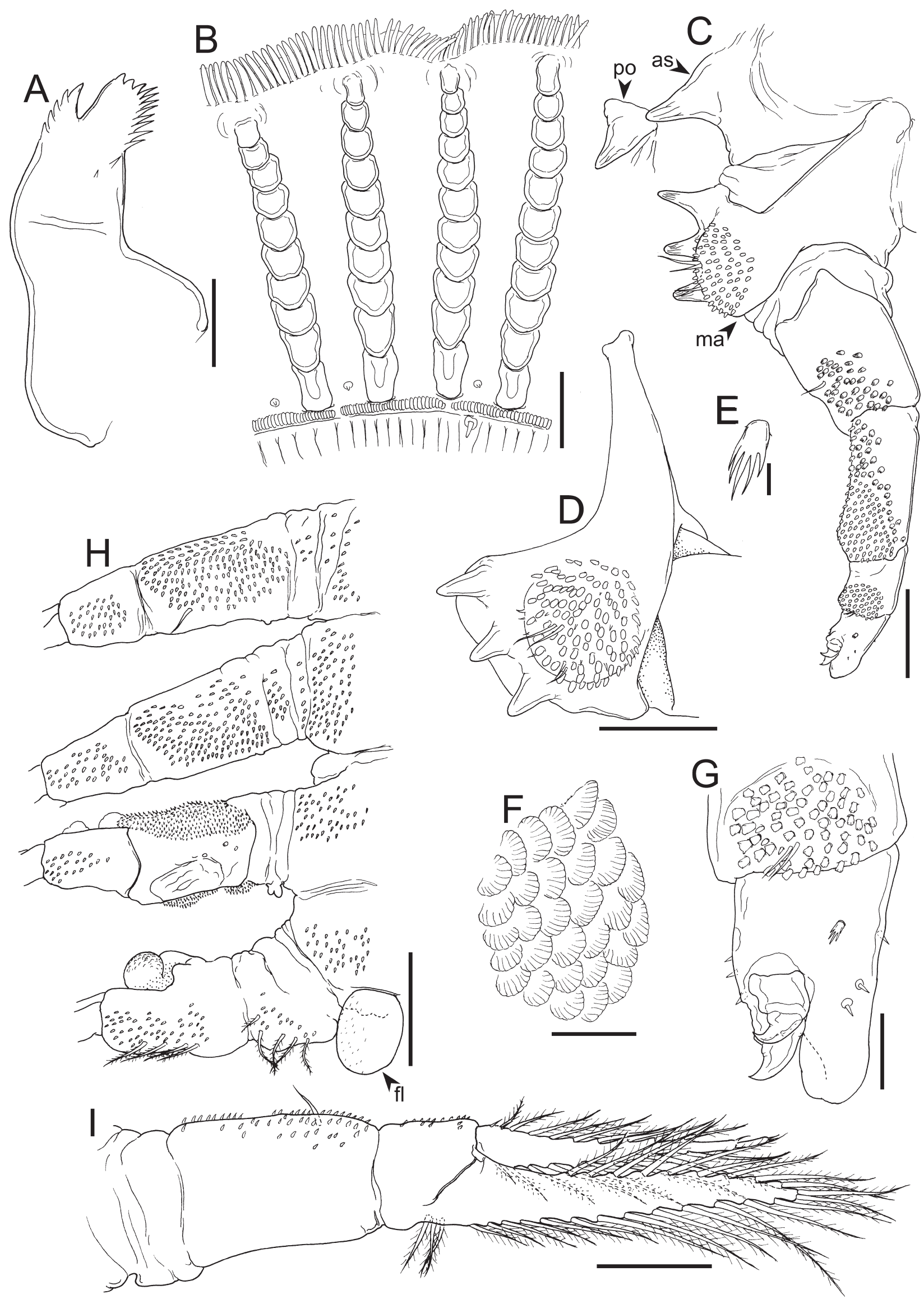

Fig. 3. Argulus quadristriatus Devaraj and Ameer Hamsa, 1977, adult male, NSMT-Cr 24635. A, left mandible, anterior; B, upper part of left maxillule, ventral. C, left maxilla (ma), accessory spine (as), and postmaxillary spine (po), anterior; D, basal plate of left maxilla, ventral; E, setose scale on second segment of left maxilla; F, patch of squamate surface on second segment of left maxilla; G, terminal segment of left maxilla, anterior; $\mathrm{H}$, coxae and bases of legs 1 to 4 and fleshy lobe (fl) on fourth thoracic somite, ventral; I, right leg 1, anterior. Scale bars: A, $0.02 \mathrm{~mm}$; B, F, $0.03 \mathrm{~mm}$; C, D, $0.2 \mathrm{~mm}$; E, $0.05 \mathrm{~mm}$; G, $0.4 \mathrm{~mm} ; \mathrm{H}, 0.3 \mathrm{~mm}$. 


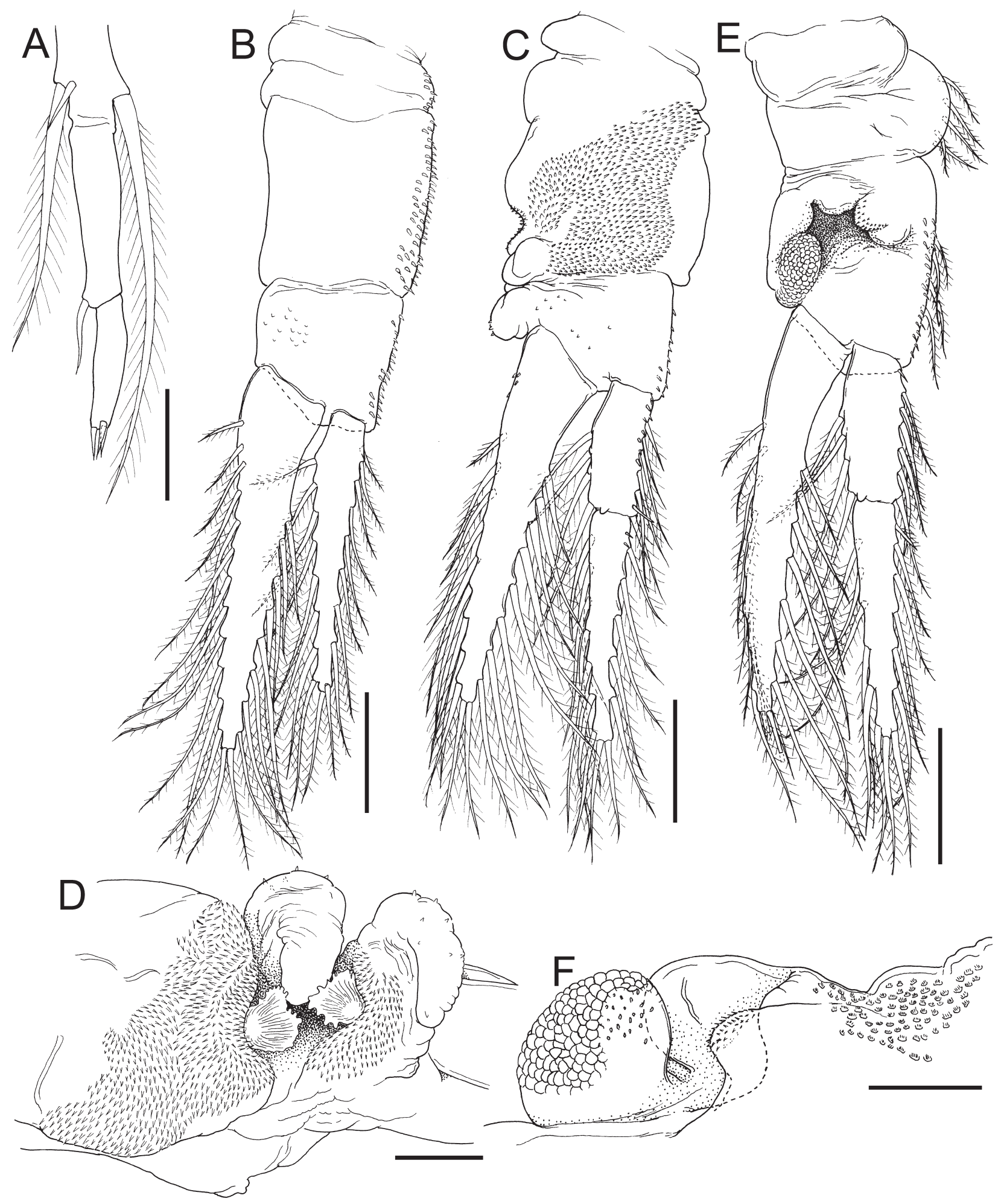

Fig. 4. Argulus quadristriatus Devaraj and Ameer Hamsa, 1977, adult male, NSMT-Cr 24635. A, distal part of endopod of right leg 1, posterior; B, right leg 2, anterior; $\mathrm{C}$, right leg 3 , anterior; D, anterior part of coxa and basis of leg 3, dorsal; E, right leg 4, anterior; $\mathrm{F}$, anterior part of basis of leg 4, ventral. Scale bars: A, $0.07 \mathrm{~mm}$; B, C, E, $0.3 \mathrm{~mm}$; D, F, $0.1 \mathrm{~mm}$.

cal tip. Preoral stylet (Fig. 2E) slender, retracted in cuticular sheath. Mouth tube (Fig. 2E) elongate bearing 15 scales proximally. Mandible (Fig. 3A) bearing two blades with five and 13 teeth, respectively. Left maxillule (sucker) (Figs $2 \mathrm{~B}, 3 \mathrm{~B}$ ) bearing 58 support rods, each composed of eight to eleven (rarely five or six) sclerites; right maxillule (sucker) bearing 61 support rods. Maxilla (Fig. 3C-G) 5-segmented; proximal segment bearing basal plate with three pointed conical processes on posterior margin and circular patch composed of numerous scales and four setae (Fig. 3D); second segment rod-like, covered with setose scales (Fig. 3E), bearing seta on ventral surface and patch of squamate sur- 


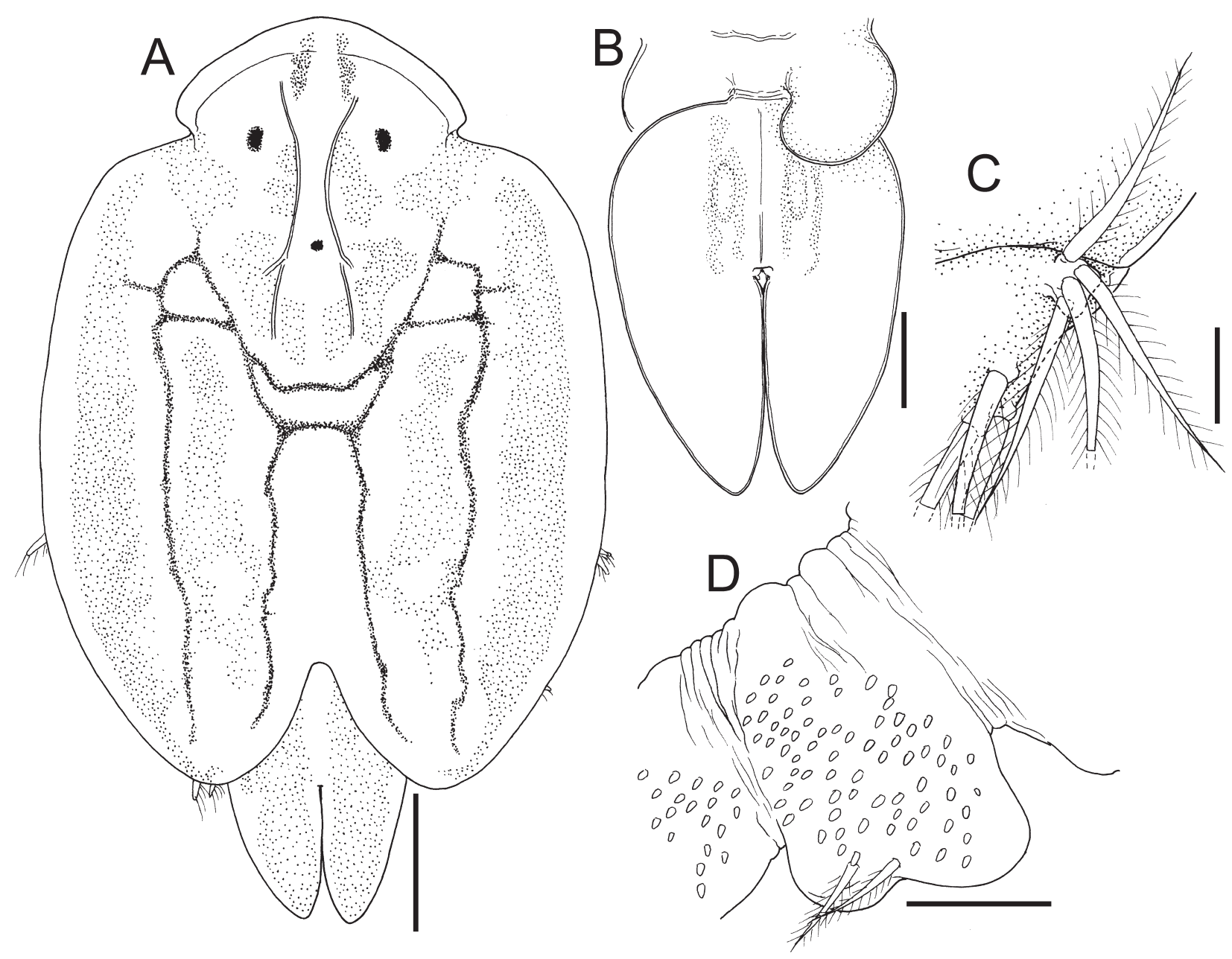

Fig. 5. Argulus quadristriatus Devaraj and Ameer Hamsa, 1977, adult female, NSMT-Cr 24635. A, habitus, dorsal; B, posterolateral lobes of fourth thoracic somite and abdomen, dorsal; C, basal part of exopod of leg 1; D, coxa of right leg 4, ventral. Scale bars: A, $1.5 \mathrm{~mm}$; B, $0.7 \mathrm{~mm}$; C, $0.1 \mathrm{~mm} ; \mathrm{D}, 0.3 \mathrm{~mm}$.

face posteriorly (Fig. 3F); third segment rod-like, covered with setose scales and spatulate scales; fourth segment small, with patch of spatulate scales distally, bearing two setae (Fig. $3 \mathrm{G})$; terminal segment with blunt tip, bearing two claw-like spines, six small spinules, and setose scale. Accessory spine (Fig. 3C) conical, situated adjacent to base of maxilla. Postmaxillary spine (Fig. 3C) conical.

Legs 1 to 4 (Figs 3H, I, 4A-F) biramous, composed of coxa, basis, and both rami. Leg 1 (Figs 3H, I, 4A) elongate; coxa covered with spinules, bearing seta on ventral surface; basis small, covered with spinules; exopod unsegmented, elongate with 16 plumose setae on outer margin, two plumose distal setae, and nine plumose inner setae; endopod 3 -segmented, bearing single simple and eight plumose setae on outer margin and nine plumose and two simple setae on inner margin of proximal segment, simple outer seta on middle segment, and three simple distal setae on terminal segment. Leg 2 (Figs $3 \mathrm{H}, 4 \mathrm{~B}$ ) elongate; coxa covered with spinules; basis small, covered with spinules; exopod elongate, unsegmented, with 12 plumose setae on outer margin, two plumose distal setae, and eight plumose inner setae; endopod unsegmented, with eight plumose setae on outer margin, two distal plumose setae, and eight plumose setae on inner margin. Anterior surface of coxae and bases of legs 3 and 4 modified as accessory sexual apparatus. Leg 3 (Figs $3 \mathrm{H}, 4 \mathrm{C}, \mathrm{D}$ ) elongate; coxa covered with spinules, bearing massive distal protuberance and distal foliate peg with serrate margin; basis small, partially covered with spinules, bearing massive protuberance and foliate peg with serrate margin; exopod elongate, unsegmented, with nine plumose setae on outer margin, two distal plumose setae, and eight plumose setae on inner margin; endopod 2-segmented, its proximal segment with four plumose setae on outer margin, six plumose and simple setae on inner margin, and terminal segment with seven plumose setae on outer margin, two distal plumose setae, and five plumose setae on inner margin. Leg 4 (Figs 3H, 4E, F) elongate; coxa bearing natatory lobe on posteroventral surface with five plumose setae; anterior surface of basis with two small lobes and large spherical swelling with scaly surface, posterior surface with four setae; exopod elongate, unsegmented, with nine plumose setae on outer margin, two distal plumose setae, and seven plumose setae on inner margin; endopod 2-segmented, bearing comprising proximal segment with four plumose setae on outer margin and single simple and six plumose setae on inner margin and terminal segment with six plumose setae 
on outer margin, two distal plumose setae, and six plumose setae on inner margin.

Description of adult female. Body (Figs 1D, 5A) 7.6810.59 long $(n=4)$, comprising cephalon, four thoracic somites, and abdomen. Cephalon longer than wide, 6.19-9.00 $(7.73 \pm 1.20) \times 4.18-6.03(5.28 \pm 0.83)$, bearing pair of compound eyes and nauplius eye, compound eye bean-shaped, $0.23-0.29(0.27 \pm 0.03)$ long, with medial cleft on middle of abdomen and pair of carapace lobes; ventral surface covered with pointed spinules on frontal region and lateral margins;; respiratory areas as in male. First to fourth thoracic somites densely ornamented with spinules on ventral surface; fourth thoracic somite bearing pair of posterolateral lobes dorsally (Fig. 5B). Abdomen (Fig. 5B) bilobate, longer than wide, $2.28-3.66(3.04 \pm 0.57) \times 1.54-2.65(2.12 \pm 0.48)$, bearing caudal rami. Caudal rami as in male, longer than wide, 0.05-0.07 (0.06 \pm 0.01$) \times 0.03-0.04(0.04 \pm 0.01)$.

General shape of antennule, antenna, other mouthparts, and thoracic legs 1 to 4 as in adult male, except as follows: exopod of leg 1 bearing knob-like process (Fig. 5C) (rudimentary flagellum) on outer margin with five plumose setae; coxa and basis of leg 3 and basis of leg 4 unmodified; natatory lobe of leg 4 well developed (Fig. 5D).

Developmental stage, male. General body shape and appendages as in adult male. Left maxillule (sucker) bearing 59 support rods composed of mainly five or six sclerites. Body 2.28 long $(n=1)$. Cephalon longer than wide, $1.98 \times 1.22$. Compound eye 0.10 long. Abdomen longer than wide, $0.71 \times 0.46$. Caudal rami longer than wide, $0.03 \times 0.02$.

Developmental stage, female. General body shape and appendages as in adult female. Left maxillule (sucker) bearing 59 support rods composed of mainly five or six sclerites. Body 3.90 long $(n=1)$. Cephalon longer than wide, $3.03 \times 2.00$. Compound eye 0.20 long. Abdomen longer than wide, $1.04 \times 0.68$. Caudal rami longer than wide, $0.03 \times 0.02$.

Coloration. Fresh specimens of both sexes with black pigmentation on dorsal surface of carapace and abdomen (Fig. 1C, D), concentrated into U-shaped, four long longitudinal, and three short horizontal lines. These lines still visible on specimens fixed in 99\% ethanol (Figs 2A, 5A).

Infection sites. Body surface of host fish on head and on trunk near pectoral fin base.

Remarks. Argulus quadristriatus was originally described based on a single adult female from the body surface of a specimen of Psammoperca waigiensis (Cuvier, 1828) (Perciformes: Latidae) collected in Palk Bay off Mandapam, southern India (Devaraj and Ameer Hamsa 1977). There are no significant differences in morphological features between the holotype female and the female specimens in this study, except for the mandible having two blades both with numerous fine teeth in the holotype ( $v s$. five and 13 teeth) and an abnormally modified right leg four in the holotype (see Devaraj and Ameer Hamsa 1977; present study). Since some morphological features of the holotype were inadequately described or completely overlooked in the original description, re-examination of the holotype could reveal additional differences from the new Japanese material and provide insight into the variability of this species.
Newly proposed Japanese name for A. quadristriatus. He-kabui-umi-cho, meaning "a marine argulid coated by volcanic ash" in the dialect of Kagoshima, southern Japan, a place famous for the active volcano, Sakurajima, in Kagoshima Bay.

\section{Discussion}

In total of 10 species of the genus Argulus are now known from Japanese waters (Nagasawa 2009, 2011; present study). Four of these species (A. americanus Wilson, 1902, A. coregoni Thorell, 1865, A. japonicus Thiele, 1900, and A. lepidostei Kellicott, 1877 or a similar species) have been recorded from freshwaters and the remaining six species (A. caecus Wilson, 1922, A. kusafugu Yamaguti and Yamasu, 1959, A. matuii Sikama, 1938, A. onodai Tokioka, 1936, A. quadristriatus, and A. scutiformis Thiele, 1900) from marine waters. A specimen of $A$. quadristriatus was collected from brackish waters in a river mouth of Okinawa-jima island in this study. Argulus quadristriatus bears only one posterior spine on the proximal segment of antennule in both sexes and thereby differs from five of the above species (A. caecus, $A$. kusafugu, A. matuii, A. onodai, A. scutiformis), which carry two posterior spines, as well as from A. lepidostei, which lacks any posterior spines (see Kellicott 1877; Wilson 1902, 1916, 1922; Thiele 1904; Tokioka 1936; Sikama 1938; Yamaguti and Yamasu 1959). Argulus americanus, A. coregoni, and A. japonicus differ from A. quadristriatus in having no spines or scales on the basal half of the mouthtube (vs. ornamented with scale-like spines) (see Tokioka 1936; Wang 1958; Yeatman 1965; Cressey 1972; Shimura 1983; Shimura and Asai 1984). According to Nagasawa (2009), several unidentified species of the genus Argulus reported from Japanese waters were probably A. coregoni, A. japonicus, $A$. matuii, or A. scutiformis. Thus, the discoveries of A. quadristriatus in this study represent the first records of this species from Japanese waters. They are also the first records from the North Pacific Ocean including the East China Sea, and only the second set of records globally.

Since this branchiuran was previously reported only from Psammoperca waigiensis (Devaraj and Ameer Hamsa 1977), the three species of teleost host reported here, Upeneus tragula, Parupeneus ciliatus, and Favonigobius reichei, are all new hosts.

\section{Acknowledgments}

We thank Dr Yuji Ikeda (Biological Laboratory), Mr Koji Abe (Ginowan City), Mrs Yukari Kashiwagi (Kagoshima City Aquarium), Dr Ryuta Yoshida and Mr Shota Samejima (University of the Ryukyus) for providing specimens, and Mr Akinobu Isobe (Higashi-Sakurajima Fishery Cooperative) for his lecture of the local language of Kagoshima. Part of this work was supported by Japan Society for the Promotion of Science (JSPS) KAKENHI Grant No. JP15H06517. 


\section{References}

Benz, G. W. and Otting, R. L. 1996. Morphology of the fish louse (Argulus: Branchiura). Drum and Croaker 27: 15-22.

Boxshall, G. 2005. Branchiura (fish lice). Pp. 145-147. In: Rohde, K. (Ed.) Marine Parasitology. CSIRO Publishing, Collingwood, and CABI Publishing, Wallingford.

Cressey, R. F. 1972. Biota of Freshwater Ecosystems Identification Manual No. 2. The genus Argulus (Crustacea: Branchiura) of the United States. Environmental Protection Agency, U.S. Government Printing Office, Washington DC, $14 \mathrm{pp}$.

Devaraj, M. and Ameer Hamsa, K. M. S. 1977. A new species of Argulus (Branchiura) from a marine fish, Psammoperca waigiensis (Cuvier). Crustaceana 32: 129-134.

Humes, A. G. and Gooding, R. U. 1964. A method for studying the external anatomy of copepods. Crustaceana 6: 238-240.

Kellicott, D. S. 1877. Description of a new species of Argulus. Bulletin of the Buffalo Society of Natural Sciences 3: 214-216.

Müller, O. F. 1785. Entomostraca seu Insecta Testacea, Quae in Aquis Daniae et Norvegiae Reperit, Descripsit et Iconibus Illustravit Otho Fridericus Müller. Sumtibus J.G. Mülleriani, 1785, Havniae, 134 pp, XXI pls.

Nagasawa, K. 2009. Synopsis of branchiurans of the genus Argulus (Crustacea, Argulidae), ectoparasites of freshwater and marine fishes, in Japan (1900-2009). Bulletin of the Japanese Society of Biogeography 64: 135-148. [In Japanese with English abstract]

Nagasawa, K. 2011. The biology of Argulus spp. (Branchiura, Argulidae) in Japan: a review. Pp. 15-21. In: Asakura, A. et al. (Eds) Crustacean Monographs, 15. A New Frontiers in Crustacean Biology: Proceedings of the TCS Summer Meeting, Tokyo, 20-24 September 2009. Brill, Leiden.

Neethling, L. A. M., Malta, J. C. O., and Avenant-Oldewage, A. 2014. Additional morphological information on Dipteropeltis hirundo Calman, 1912, and a description of Dipteropeltis campanaformis $\mathrm{n}$. sp. (Crustacea: Branchiura) from two characiform benthopelagic fish hosts from two northern rivers of the Brazilian Amazon. Zootaxa 3755: 179-193.

Poly, W. J. 2008. Global diversity of fishlice (Crustacea: Branchiura: Ar- gulidae) in freshwater. Hydrobiologia 595: 209-212.

Poly, W. J. 2009. Branchiura (Crustacea) of the Gulf of Mexico. Pp. 837840. In: Felder, D. L. and Camp D. K. (Eds) Gulf of Mexico-Origins, Waters, and Biota. Biodiversity. Texas A\&M University Press, College Station, Texas.

Shimura, S. 1983. SEM observation on the mouth tube and preoral sting of Argulus coregoni Thorell and Argulus japonicus Thiele (Crustacea: Branchiura). Fish Pathology 18: 151-156.

Shimura, S. and Asai, M. 1984. Argulus americanus (Crustacea: Branchiura) parasitic on the bowfin, Amia calva, imported from North America. Fish Pathology 18: 199-203. [In Japanese with English abstract]

Sikama, Y. 1938. On a new species of Argulus found in a marine fish in Japan. Journal of the Shanghai Science Institute, Section III 4: 129-134.

Thiele, J. 1904. Beiträge zur Morphologie der Arguliden. Mitteilungen aus dem Zoologischen Museum, Berlin 2: 5-51, pls 6-9.

Tokioka, T. 1936. Preliminary report on Argulidae found in Japan. Annotationes Zoologicae Japonenses 15: 334-343.

Yamaguti, S. and Yamasu, T. 1959. On two species of Argulus (Branchiura, Crustacea) from Japanese fishes. Biological Journal of Okayama University 5: 167-175.

Yeatman, H. C. 1965. Redescription of the freshwater branchiuran crustacean, Argulus diversus Wilson, with a comparison of related species. Journal of Parasitology 51: 100-107.

Wang, K. N. 1958. Preliminary studies on four species of Argulus parasitic on fresh-water fishes taken from the area between Nanking and Shanghai, with notes on the early larval development of Argulus chinensis. Acta Zoologica Sinica 10: 322-335. [In Chinese with English summary]

Wilson, C. B. 1902. North American parasitic copepods of the family Argulidae, with a bibliography of the group and a systematic review of all known species. Proceedings of the United States National Museum 25: 635-742, pls 8-27.

Wilson, C. B. 1916. Copepod parasites of fresh-water fishes and their economic relations to mussel glochidia. Bulletin of the United States Bureau of Fisheries 34: 333-374, pls 60-74.

Wilson, C. B. 1922. Parasitic copepods from Japan, including five new species. Arkiv för Zoologi 14: 1-17, pls 1-4. 